\title{
Mental Time Travel in Shakespeare's Sonnets: Aesthetic Art in Neuropsychological Perspectives
}

\author{
Mufeed Al-Abdullah ${ }^{1}$ \\ ${ }^{1}$ Department of English, College of Arts, Jerash University, Jerash, Jordan \\ Correspondence: Mufeed Al-Abdullah, College of Arts, University of Jerash, Jerash, Jordan, 26150. E-mail: \\ mufeedh2014@gmail.com
}

Received: January 12, $2020 \quad$ Accepted: February 16, 2020 Online Published: February 26, 2020

doi:10.5539/ells.v10n1p67 URL: https://doi.org/10.5539/ells.v10n1p67

\begin{abstract}
This study means to analyze Shakespeare's use of mental time travel (MTT) in his collection of sonnets, especially those addressed to his young friend. It also hopes to amplify that Shakespeare's versification of MTT anticipates modern neuropsychological studies on the topic. The article tackles MTT in light of four different premises induced from the sonnets subject to analysis: first, MTT occurs in the sonnets in correlation with objective time; second, the dual constructive and destructive nature of time triggers the need for the memory-based MTT; third, the disparaging effect of time on the poet and the friend's mother is meant to stimulate the young friend to heed the future of his extraordinary beauty under the strokes of ruthless time; and, fourth, the destructive force of time on non-human beings and natural phenomena provides another stimulus to urge the young friend to heed the dangers of time on his future.
\end{abstract}

Keywords: episodic memory, future memory, life cycle, mental time travel, neuropsychology, objective time, subjective time

\section{Introduction}

Time is a major subject in Shakespeare's sequence of sonnets. Noticeably, the word "time" is mentioned seventy-nine times in the collection along with other relevant words like seasons, week, day, hours, and minutes (Shen \& Liu, 2016, p. 103; Moreira, 2017, p. 250). The theme of time was of paramount importance and turned into an obsession in the Renaissance mind. This is evident in taking interest in clocks and clock-making (Moreira, 2017). Moreira points out other reasons behind the pervasiveness of the concept of time in Elizabethan literature, such as the scientific revolution which began in 1543, the geographic discoveries in the new world, and the rise of Protestantism, which focused on the impermanence of human life and the pessimistic awareness of the passage of time (2017).

Moreover, Shakespeare who wrote for an age of dualism maintained some of the medieval features of time like measuring time by the alternation of day and night and the flux of seasons along with Renaissance concepts of measuring time by clocks, hours, and minutes. Both the natural and mechanical concepts refer to what is called objective time, chronological time, or clock time. Objective time is sequential and moves in one direction irrelevant to human consciousness and feelings. However, Shakespeare also presents another form of time which modern psychologists call subjective time. This form is memory-based and non-sequential due to the ability of the conscious mind to project itself back and forth to various periods of life. This ability to post-experience or pre-experience events or moments in the stream of time is what psychologists also call mental time travel (MTT) (Corballis, 2013; Szpunar, 2011). Besides, Corballis (2013) considers MTT as a major constituent of "mind wandering," which engages more than half of people's waking time (p. 1). A major element of mind-wandering is memory where mind wanderings are formulated. Suddendorf and Corballis (2007) define MTT as the mental ability to reconstruct past incidents and predict future by projecting the self to "imagined future and imagined past" (Corballis, 2013, p. 2). Recent neuropsychological studies conclude that mind-wandering triggers several neural activities in the frontal and parietal lobes in the brain, more to the frontal lobe activity when projecting the self to the future, and more to parietal when reconstructing a past experience (Addis, Wong, \& Schacter, 2007).

This article aims to analyze the nature and various forms of MTT in Shakespeare's collection of sonnets, especially those addressed to the poet's beautiful young friend, known as the 'golden lad' (Horst Breuer, 2004) or the 'Fair Youth' (Moreira, 2017). The study also demonstrates that time has a dual constructive and 
destructive nature. Time takes us from childhood to maturity, on the constructive side, but then to degeneration and devastation, on the destructive side. It also endeavors to amplify that Shakespeare's versification of subjective time anticipates modern neuropsychological studies on the topic.

\section{Review of Literature}

In Shakespeare's time, there was an increasing interest in objective time because of the great strides the Elizabethans had in the making of mechanical clocks compared with the "rudimentary, imprecise objects, even less precise than some clepsydras (water clocks)" used in Middle Ages (Moreira, 2017, p. 250). Moreira adds that in medieval culture, people's conception of time was basically "natural and ecclesiastical, ...[and] obeyed both the rhythm of the seasons and that of church bells," (p. 250). Besides, people of the Renaissance era welcomed the advancements made in clock-making that enabled them to measure time in sub-divisions of hours and minutes. Moreira (2017) adds that one reason behind this attention to the precision of time was their worry about the mutability and uncertainty of life with the Copernican theory that affirmed that the sun, not the earth, was the center of the universe. People measured time by the clock because of the perception that every hour advanced the individual's life to death, or as Kerrigan puts it: "every clock declared that an hour of life, considered another way, was an exact, irretrievable hour nearer death" (cited in Moreira, 2017, p. 250). Therefore, Shakespeare's versification of the Elizabethan fashionable theme of objective time, especially in the sonnets, positions him within the traditions of Elizabethan intellectual framework. Although Shakespeare was a representative of his age, he is, in fact, "a man for all ages," according to Moreira (2017, p. 250). What makes Shakespeare universal in this context is his versification of subjective time. What he contributes on this theme anticipates the most recent theories on subjective time in the field of neuropsychology. The major share of this study will be devoted to the discussion of MTT as a form of subjective time. Therefore, it is in order to review relevant studies on the subject.

The separation between objective and subjective time was not a Shakespearean idea. Manning et al. (2013) point out that St. Augustine introduced such a distinction in respect to time. For him, objective time is a chronological progression, whereas subjective time is a "self-conscious, memory-based, subjective phenomenon" (p. 236). For Szpunar (2011) objective time deals with the physical reality of the present, whereas subjective time deals with past and future time which are a part of a unified human presence and can only exist in the human mind (p. 236). He discusses the concept of subjective time and relevant issues, such as the capacity to be conscious of subjective time and the relation between subjective time and the brain. This concept is related to the 'past' and 'future', which physically do not exist, but are simply inventions of the human mind. So, this sort of time is not the clock time we are familiar with in the physical world. Subjective time develops a sense of continuous existence in the world. Szpunar (2011) points out that there is an increase in the studies in psychology and neuroscience that examine the relation between reconstructing the past and forecasting the time to come. This mental process is metaphorically known as MTT (Suddendorf \& Corballis, 1997, 2007).

Tulving (2002) considers 'chromesthesia' as another term for subjective time. Szpunar (2011) clarifies that in order to understand subjective time, it is important to differentiate between the ability to be conscious of subjective time or 'chronesthesia' and the associated activities in the brain that come with it. Tulving and Kim (2007) call these two facets of MTT, the medium and message. The medium refers to the capacity that empowers the mental activities, i.e., the message. The capacity of chronesthesia enables the mind to remember past events and forecast future plans and incidents. Chronesthesia is another term for what Dalla Barba calls 'temporal consciousness,' which involves a "temporal existence for the subject" (Szpunar, 2011, p. 409). A similar term for chronesthesia is Tulving's 'autonoetic concept' (Szpunar, 2011, p. 409). Both terms denote the consciousness of subjective time in which the self exists, whereas the other focuses on the self, "existing in subjective time" (Szpunar, 2011, p. 410). This peculiar difference is important because both time and the self can be studied independently. However, the bond between time and self is a significant one because of the capacity chronesthesia or autonoetic consciousness empowers the individual to self-project the self to "re-experience" or "pre-experience" life events or subjects (Szpunar, 2011, p. 410). Furthermore, chronesthesia indicates an important mental capacity that enables humans to project themselves to situations that are not present, such as the past and future. But how does the mind empower this capacity? Szpunar (2011) argues that neurologically, the frontal, temporal, and parietal lobes of the brain participate in the process of re-experiencing the past and forecasting the future. He emphasizes that it is pivotal for future studies to distinguish between the awareness of MTT as a capacity and the activities of the brain that are triggered to empower it. Neuropsychological studies believe that there are neural substrates of mental time travel as clear from the observation that there is impairment in the awareness of chronesthesia in people who suffer from damage in the prefrontal cortex of the brain. In contrast, Hassabis and Maguire (2007) believe subjective time is a mental feature of the brain, and that 
the conventions of past and future are merely a means of arranging human thought. Similarly, Szpunar (2011, p. 411) holds that the interest in subjective time and the metaphoric MTT requires a serious examination of how the human mind is capable of dislocating itself across different periods in the flux of time.

More relevant to the concern of this study is the article of Arzy, Collette, Ionta, Fornari and Blanke (2009) in which they argue that mental time (MT) is a major feature of human experience and is established by self-projection of the individual self to various past and future points in time. The authors go beyond this concept to add self-projection of one's face at different past and future moments in the current of time. They notice that the event and face oriented self-projection have major features that indicate (a) similarity between memories of the past and the future, (b) making possible the judgments about the future and the past, and (c) making possible evaluation of various experiences that are remote from the present moment (Arzy et al., 2008). These effects show that MT mechanisms are not concerned with the position of experience in the past or the future. Dislocating the self in time is a major feature of MT drawing on neural activities that encode "memory, mental imagery and the self" (Arzy et al., 2008, p. 2009).

The human mind has the capacity to project itself to past and future points in time, indicating subjective mental experience of time (Tulving, 1985; Schacter, Addis, \& Buckner, 2007). MT draws on an autobiographical memory that allows the individual to reconstruct a past episode by projecting oneself into past moments of time. Future memory is to dislocate oneself forward to pre-live an incident in the time to come (Tulving, 1985). Self-projection in time is changing the habitual location of the mind backward or forward. Scientists confirm that the hippocampus plays a very important role in this process of MTT. Studies have shown that any damage in the hippocampus leads to amnesia and the inability to remember past events or think of future ones (Hassabis \& Maguire, 2007). Neurological studies indicate that the hippocampus is the center that arranges information derived from other lobes of the brain, including events from the past and plans for the future (Addis et al., 2007). Szpunar, Watson, and McDermott (2007) notice that the anterior hippocampus is more stimulated when engaged with future episodes and the posterior hippocampus is more activated when involved with past events. The study of Arzy et al. (2009, p. 2009) is helpful in understanding Shakespeare's presentation of MTT, using the face stimulus in the early sonnets. To visualize future experiences, creating consciousness of the future and past events, Shakespeare creates patterns for the prospective appearance the young man is going to look like in the future. He simultaneously imagines what the son of the young man will look like when he becomes young like his father now. He foresees what the young man is marching towards.

Another concept that has attracted scholars in the last thirty years is future memory which is considered a major aspect of MTT. Ingvar (1985) coins the expression in a neurological study with the same title. He tries to allocate the activities of temporal awareness of the past, present, and future components of time to the lobes of the cerebral cortex. He associates our experience of the past to memory mechanisms that are functionally related to the various parts of the cerebral cortex called the temporal lobe. The consciousness of the present experience is achieved by the sensory input which motivates a conscious awareness of inner Now-situation irrelevant of the afferent impulses conveyed to the brain. The most important discussion of Ingvar is devoted to the experience of future time, which is not yet. Ingvar (1979) maintains that memory enables individuals to lay out "alternative hypothetical behavior patterns in order to be ready for what may happen" (p. 21). He calls this process the "simulation of behavior" (p. 21). In a later article (1985), he explained that the concepts of the future can be remembered with the same clarity as those of the past (p. 128). Thus, simulated scenarios meant to prepare or plan for future events can be recalled from the repertoire retained in the prefrontal cortex, exactly like memories of time past recollected from the temporal lobe. Furthermore, future memory can play an important part in the "adaptive nature of human cognition" (Szpunar et al., 2013, p. 1). Some studies differentiate between future memory and imagination. These studies have demonstrated that future "memories and simulated events" relate to the structure of consciousness, intentionality, and perception, whereas imagined events are marked for "their cognitive operations" (Szpunar et al., 2013, p. 2). Klein, Robertson, Delton, and Lax (2012) notice that acquaintance and personal experience are important factors in enhancing future simulation and motivating the "mnemonic advantage associated with future-oriented encoding processes" (Szpunar et al., 2013, p. 2). More recently, Bar (2007) points out that the major role of MTT is to provide scenarios by combining past experiences and future predictions and to save those mental memories to be utilized in future plausible situations. He bases this judgment on "associative processing," whose primary function is the generation of forecasts (p. 29). Klein et al. (2010) suggest that experience has a significant impact on "cognitive mechanisms that use earlier information to plan behavior" (p. 234).

Arzy et al. (2009) argue that "the activation of neural regions, the importance of self-projection for MT processing is also suggested by the activation of brain regions outside the classical memory areas that were 
found to be recruited for MT, including the posterior parietal cortex, which is probably related to visual imagery and autobiographical memory" (p. 2009). The authors studied the role of self-dislocation to the past and future, employing "the event-related functional magnetic resonance imaging (fMRI)" to examine the stimuli of faces and events. In the study, the sample subjects were exposed to their faces and the face of a famous actor at different points in time in the past, present, and future. The subjects were asked to project themselves to different points in time and indicate if changes of face or events have taken place or are yet to take place. This process enabled the researchers to test pre-experiencing and post-experiencing past and future memories with regard to the stimuli of faces and events. Participants were also asked to assess the same faces and events without dislocating themselves in MT. The results show that fMRI behavior had the same pattern for faces and events and recruited almost the same network of neural responses. They also demonstrate that traveling in time is essential for activating MT, regardless of faces and events, depending on neural mechanisms of memory, intellectual imagery, and identity.

Shakespeare's sonnets can be approached as a versification of modern theories about MT and MTT. Of course, Shakespeare was neither aware of the anatomy of the brain nor the neurological allocations of brain regions stimulated when projecting oneself to various moments in the past or future as neuroscientists do. However, he based his creative judgments on human experience and analogy with nature.

\section{Discussion}

The metaphoric concept of MTT (Suddendorf \& Corballis, 1997, 2007) in its various neuropsychological interrelated host of forms and terms, such as chronesthesia (Szpunar, 2011, p. 410), autonoetic consciousness (Szpunar, 2011, p. 410), future memory (Ingvar, 1985), and episodic memory (Corballis, 2013; Ingvar, 1979, 1985; Tulving, 1985; Addis et al., 2007), makes a prominent theme in Shakespeare's sequence of sonnets dedicated to his young friend. In these sonnets, the poet urges his friend to get married and have children that will sustain his extraordinary beauty in defiance of destructive time. In his rhetorical endeavor, Shakespeare anticipates the results of recent philosophical, and neuropsychological studies with regard to episodic memory and prospective memory discussed in the field of MTT. The poet accentuates the subject in three ways: First, he frequently correlates MTT, which is a version of subjective time, with objective time issues. Second, the poet is careful to show that time is not totally destructive, but also constructive. This remark stems from the nature of human and natural life cycles, which move irreversibly in one direction, but in a curve that grows from beginning to perfection and then declines to loss and destruction. Third, he guides the memory-based consciousness of the young man to imagine his beauty at two stages in his life when he becomes at the age of the poet and at the age of the young man's mother. The poet and the mother provide external stimuli to the targeted young man's mind as the poet guides him to undergo an MTT experience of future memory. Fourth, Shakespeare fortifies his demonstration of the prospective future memory of the young man by providing an analogy between the young man's life cycle and that of plants and natural phenomena that undergo similar mutability with the passage of time. The analogies enrich the poet's presentation with a metaphoric force that diversifies the possibilities of pre-experiences and endows the images with vividness, energy, or creativity. The study will approach the subject from these four perspectives with a selection of examples from the sonnets to support and enhance the argument.

\section{First: Correlation between objective and subjective time}

Shakespeare in the sonnets that tackle the issue of time usually combines the concepts of objective time and subjective time. The first is meant to show the menace of the universal phenomenon on human and non-human beings in our mutable impermanent world. This chronological time is the factor that puts life in our world at stake. Shakespeare in this context maintains the Aristotelean idea that is identified through change (Rassi, 2014). Shen and Liu (2016) consider that time is kinetic for Shakespeare and it accompanies and indicates change. They argue that Shakespeare, like Renaissance writers, was influenced by Aristotle's theory on time and change expressed in Physics. Furthermore, they point that there is time as long as there is change, explaining that Shakespeare's vision of time is pessimistic because it moves in a linear way (Shen \& Liu, 2016, p. 103). The following quote from Physics sheds further light on Aristotle's concept which Shakespeare adopts in his sonnets:

Just as motion is a perpetual succession, so also is time. But every simultaneous time is self-identical; for the 'now' as a subject is an identity, but it accepts different attributes. The 'now' measures time, in so far as time involves the 'before and after' (Physics, IV, 11, p. 23).

Time, for Aristotle, is a flux of identified 'now's. It should be measurable. Past and future arrange the human thought (Hassabis \& Maguire, 2007). Line 1 in sonnet 12 ("When I do count the clock that tells the time") observes this Aristotelean concept that time can be divided and measured. This concept appealed to the 
Elizabethans, who devoted much time to improving clock-making artistry. In this sonnet, Shakespeare provides five objects or phenomena that have a life cycle that constitutes a beginning, growth, maturity, decline, and end in the first two quatrains. They include the day, the violet, sable curls, trees, and grass. All these examples from nature indicate the movement of objective time, which changes things through its passage:

When I do count the clock that tells the time,

And see the brave day sunk in hideous night;

When I behold the violet past prime,

And sable curls all silvered o'er with white:

When lofty trees I see barren of leaves,

Which erst from heat did canopy the herd,

And summer's green all girded up in sheaves

Borne on the bier with white and bristly beard ... (1-8)

The third quatrain invites the correlation between objective time and subjective time. The poet, here, compares the life cycle of these phenomena with the human life cycle. Human life, like the natural listed items, will be eventually harvested by time's scythe. The beautiful young man will be subject to the conquest of time like everything else in this world:

Then of thy beauty do I question make,

That thou among the wastes of time must go,

Since sweets and beauties do themselves forsake,

And die as fast as they see others grow...

Quatrains $1 \& 2$ demonstrate the mutability of time, while quatrain 3 is a reminder for the young man of the damage that time will inflict upon his beauty. It is an invitation to have a mental journey in time to come in order to forecast what is eminently waiting for him. In order to stop the encroachment of time upon his beauty, the poet advises his friend to defend himself from the attacks of time by having a child. Progeny will sustain the beauty of the fair youth by reproducing it:

And nothing 'gainst time's scythe can make defence

Save breed to brave him, when he takes thee hence.

In the procreation sonnets, the poet does not recommend any number of children. However, in sonnet 6 , the poet recommends as many as 10 children to secure an assured survival against the damage of time:

That's for thyself to breed another thee,

Or ten times happier, be it ten for one:

Ten times thyself were happier than thou art,

If ten of thine ten times refigured thee;

Then what could Death do, if thou shouldst depart,

Leaving thee living in posterity?

As usual, the young man is reminded of future death and has to imagine what is ahead of him. That is in line with the rest of the procreation sonnets (1-17) and the MTT practice the young man is urged to carry out.

\section{Second: The dual constructive and destructive power of time}

In his presentation of time, Shakespeare reminds of its constructive and destructive dual nature. In sonnet 5, for instance, the poet reminds the fair youth of the gentle hands of time that have perfected him to be thus adorable: "Those hours, that with gentle work did frame/The lovely gaze where every eye doth dwell" (1-2). Lines 3-4 convey a warning that these same generous hands of time will turn into tyrannical destructive ones that will spoil their previous achievement and terminate it. ("Will play the tyrants to the very same/And that unfair which fairly doth excel" [3-4]), as they do to the seasons, guiding them from summer to winter. In the first two lines, the poet guides the young man to post-experience his early years in which time has led him up to his iconic beauty through reconstructing past experience through the metal capacity of episodic memory (Corballis, 2013; Ingvar, 1979, 1985; Tulving, 1985; Addis et al., 2007). In contrast, lines 2-3 urge the youth's mind to project itself to future moments in order to predict how time will “ “.. dig deep trenches in thy beauty's field,/Thy youth's proud 
livery, so gazed on now,/Will be a tattered weed of small worth held" (sonnet 2, 2-4). This version of time travel is what Ingvar (1985) calls future memory.

The same approach is used in sonnet 15 , where Shakespeare demonstrates the contradictory function of time that marches an individual to perfection and then to destruction: "When I consider everything that grows/Holds in perfection but a little moment" (1-2). In the second quatrain, Shakespeare brings to the fore the resemblance between human beings and plants in their life cycle in time:

When I perceive that men as plants increase,

Cheered and checked even by the self-same sky,

Vaunt in their youthful sap, at height decrease,

And wear their brave state out of memory ... (5-8)

The poet's explanation of the process of ascension to youth and perfection, and then descension to old age and death in human and non-human life cycles is meant to guide the young man to project himself to past experience and then to future experience at old age, i.e., to mentally travel backward and forward across the stream of his lifetime. The purpose of this reminder to the young man is to persuade him to get married and have children as means of defense against "Winter's ragged hand" (sonnet 6, line 1) and "swift-footed" (sonnet 19, line 6) "[d]evouring time" (sonnet 19, line 1). Furthermore, such poetry looks like versification of modern neuropsychological theories of future memory of Ingvar $(1979,1985)$ and MTT of Corballis (2013).

However, despite the early kindness of time at the beginning of the life cycle of human and non-human beings and natural phenomena, it turns into a destructive force after these beings or phenomena have reached a climax. The state of perfection or maturity at the peak of the life cycle of these beings and phenomena is usually followed by degeneration and devastation, ultimately ending in death. This is marked by the ending couplets of the procreation and the young man sonnets throughout the collection. In these couplets, the subject is always a reminder of mortality and death. The couplet of sonnet 1 reads as thus: "Pity the world, or else this glutton be,/To eat the world's due, by the grave and thee" (13-14). Sonnet 14 has the following couplet: "Or else of thee this I prognosticate,/Thy end is truth's and beauty's doom and date" (13-14). In the early sonnets, death is mentioned in the couplets at the end of sonnets, whereas, in the whole sequence, death is addressed in later sonnets $71-74$ and 126 .

\section{Third: MTT through the stimuli of the poet and the mother}

The stimuli used in the sonnets to convince the young man of the menace of time include firstly, the poet himself employed most frequently, and secondly, the young man's mother used only once in sonnet 3 . The poet is older than the fair youth and the mother is older than both and is probably dead. These two individuals give evidence of what the young man will look like at two different future stages in life, at future times. If we assume that the young man is in the thirties, the poet in the forties, and the mother in her fifties or dead, then the young man has two stages in his life to mentally travel to: the stage when he grows to reach the age of the poet and that when he becomes older at his mother's age. Looking at the face of his mother mirrors to the young man what damage time will inflict upon his own face and his beauty from stage to stage in his life. In sonnet 3, for instance, the fair youth is reminded that the current beauty of his face reflects that of his mother when she was his age. The distortion of her beauty now is the result of the attacks of time. However, that beauty is not lost because her son has reproduced it, thus thwarting the destructive efforts of time on her. The poet puts it as thus in quatrain three:

Thou art thy mother's glass, and she in thee

Calls back the lovely April of her prime ... (11-12)

He finally advises that if the young man wants to be remembered like his mother, he needs to have a child to remind the world of his beauty the same way he is a reminder of his mother's beauty despite her old age or death. The poet argues:

\section{But if thou live remembered not to be,}

Die single, and thine image dies with thee.

Therefore, the poet urges the young man at this golden stage of his life to think of reproducing that beautiful face at his prime time, or else he will lose that beauty and go into oblivion. He starts the poem with a piece of advice: "Look in thy glass, and tell the face thou viewest/Now is the time that face should form another" (1-2). MTT is indicated by the poet's remark that the beautiful face of the young man is, in fact, a reconstruction of the mother's face when she was his age, an idea that is derived from episodic memory (Corballis, 2013; Ingvar, 1979, 
1985; Tulving, 1985; Addis et al., 2007) by projecting the young man's mind to a period in the past when the mother was his same age now, and inviting the young man to imagine the future wrinkles on his face as he gets older, or experience what Ingvar calls future memory (1985). Projecting the self to a certain phase in the time to come is thus doubly practiced by both the poet and the young man. It is worthy to mention here that the use of faces as stimuli for future projection is of what the self anticipates (Arzy et al., 2009). That article examined the responses of the study subjects to their faces and events and the face of a familiar actor at different stages of life to guide them along a mental journey in time and register the neurotic activities of the brain that accompany the process.

Later, in sonnets $71-74$, the poet guides the mind of the young lover to pre-experience a horrid period in the future when the poet reaches the end of his life cycle. In fact, the poet and the young lover are meant to project themselves to that future stage when time conquers and subjugates the life of the poet. This is a perfect exercise of Ingvar's future memory (1985), and Corballis' mental wandering and MTT (2013). In sonnets 71 and 72, the poet invites the young lover not to mourn him for long after that stage in order not to shame himself ("After my death (dear love) forget me quite,/For you in me can nothing worthy prove" [sonnet 72;3-4]). In sonnet 73, the poet projects himself to a point in time when he is old and waiting at the threshold of death. Mind-wandering, here, is for both the poet and the young lover, who are to imagine the poet later when he becomes old in his fall season, "When yellow leaves, or none, or few do hang/Upon those boughs which shake against the cold" (2-3). He guides the mind of the youth as thus:

In me thou seest the twilight of such day

As after sunset fadeth in the west,

Which by and by black night doth take away,

Death's second self, that seals up all in rest.

A step further into the future, the poet will depart into the hereafter, leaving the young man, who is expected to love him more after his departure ("This thou perceiv'st, which makes thy love more strong,/To love that well, which thou must leave ere long" [13-14]). The poet projects himself a step further in sonnet 74 when he imagines what will happen to him after death. His body will be a dish for the worms, whereas his soul will remain to be loved by the young man. He explains:

The prey of worms, my body being dead;

The coward conquest of a wretch's knife,

Too base of thee to be remembered.

The worth of that, is that which it contains,

And that is this, and this with thee remains.

The purpose of guiding the young man in a process of MT is to persuade him to quit his destructive selfishness and regenerate his beauty which is a gift from Nature. In numerous sonnets, the poet endeavors to warn the fair youth against egocentricity that will lead to his and the world's lament over the loss of that gorgeousness he has. Horst Breuer maintains that the "golden lad['s]" theme is that selfishness will destroy his allure (Breuer, 2004, p. 66). Shakespeare's creativity in using MTT through future memory goes beyond the human life cycle of both the poet and the young man in sonnet 81 when both of them will be dead. The poet is not sure who will outlive the other. But in all cases, the young man's extraordinary beauty will be immortalized in the poet's verse and seen by "eyes not yet created" (10) and recited by "tongues to be" (11). Forecasting the future beyond the lives of the poet and the young lover converges with the modern concept of "associative processing" which results in future predictions (Bar, 2007). According to Bar (2007), the main function of MTT is to develop scenarios based on joining past experiences and future projections and save these scenarios to prepare scripts for plausible future situations. Similarly, Klein et al. (2010) suggest that MTT has an influence on cognitive techniques that use past information and events to plan future activities.

\section{Fourth: Analogy with nature:}

The poet enforces his idea of the destructive nature of time by making an analogy between the young man and other natural phenomena and plants which also undergo mutability under the passage of time. The poet presents himself as a rhetorician who personally reflects on the present beauty of the fair youth and projects himself to future moments to show the mutations that the young lover will undergo in the procession of time. The speaker does rarely project the young man to past allocations in time. He concentrates on MTT from the vantage point of the present to prospective locations in future time through Ingvar's (1985) future memory. The sonnets of 
Shakespeare richly demonstrate the MTT of the poet from the present moment into the time that is not yet. The poet dislocates himself to prospective moments through future memory to describe the imminent future the fair youth is traversing to. Furthermore, he suggests mechanisms to enable the young man to defy the impending conquest of time upon his beautiful face, namely procreation, poetry, and true love (Shen \& Liu, 2016).

Shakespeare creates a network of analogies between the circannual turning of the seasons of the year and the stages of the life cycle of the young man. The whole year in this analogy is compared with the life of the youth. Each of the four seasons is compared to a stage in the life of the young man; spring with youth, summer with manhood, fall with old age, and winter with death. In some sonnets, winter stands for both old age and death. The current stage of the youth is equivalent to summer in nature with all the positive attributes that come with it. In sonnet 2, for instance, the poet warns the fair youth of the losses and dangers winter (old age and death) will bring about which will take a toll on the alluring beauty of the young man. Winter will be a conqueror that will turn the young man's beauty and body into a worthless state:

When forty winters shall besiege thy brow,

And dig deep trenches in thy beauty's field,

Thy youth's proud livery, so gazed on now,

Will be a tattered weed of small worth held ...

The poet urges him to have a child who can save the natural gifts bestowed on him at his old age. Shakespeare's invitation to the young man to imagine what will happen to him at the age of forty is basically an invitation to practice the capacity of the mind to project the self to a period of time to come and imagine what will be the situation and state at that stage of life. This Shakespearean creative approach converges with modern theories of the neuropsychology of MTT and future memory. The same analogy between life and the seasons is utilized in sonnet 6 as the caring poet warns the young man not to allow old age and death to deform his current beauty:

Then let not winter's ragged hand deface

In thee thy summer, ere thou be distilled ...

The poet provides him with the magic solution of procreation as a defence against the assaults of time:

Then what could death do if thou shouldst depart,

Leaving thee living in posterity?

Again, in this sonnet, Shakespeare indicates the process of MTT and future memory for predicting the future along the lines of modern theory. Along the same lines, Shakespeare describes the life cycle of the young man to the circadian journey of the majestic sun from dawn to dusk in sonnet 7 . The journey takes the resemblance of human life cycle in having a birth at dawn, ascending the dome of heaven like a vigorous youth, reaching the summit of the dome at noon like a mature person, then declining towards the horizon at sunset like an old man, and finally plunging into darkness like a dead man. The adorable young man at the current stage of his life is similar to the sun at noon with his solar majesty and allure. The second quatrain represents the present stage of the young which converges with the sun at noon:

And having climbed the steep-up heavenly hill,

Resembling strong youth in his middle age,

Yet mortal looks adore his beauty still,

Attending on his golden pilgrimage ...

The first quatrain is devoted to the rise of the sun from the horizon with fascinating colors of dawn which are admired by everybody. The third quatrain describes the decline of the sun from his majestic zenith downward to sunset and sinking into darkness. The analogy is persistent from beginning to end. The present experience of the young man is that of maturity which matches midday for the sun. The first stage of birth to youth is now gone and does not exist anymore. The third stage of old age to death is the future which does not exist either. The young man is, in effect, invited to reconstruct his beautiful past experience of youth through episodic memory (Corballis, 2013; Ingvar, 1979, 1985; Tulving, 1985; Addis et al., 2007) and predict the following stage of his life through future memory (Ingvar, 1985). This implied MTT dictated by the analogy is meant to warn the beautiful young man that he will ultimately die and be lost in oblivion if he does not get a child ("So thou, thyself outgoing in thy noon,/Unlooked on diest, unless thou get a son" [13-14]). In all cases, Shakespeare draws and recruits images from natural life, especially from the four seasons, day, and night to create resemblances to the fluctuations of human life across the flux of time. These analogies provide richness and vividness to the 
recurrent ideas and emotions in the sonnets.

\section{Conclusion and Impact}

The study has examined Shakespeare's uses of the dominant phenomenon of MTT in all its manifestations presented in the modern neuropsychological theories, tracing them in sonnets of Shakespeare addressed to his anonymous young friend referred to as Mr. W. H. The study analyzes the phenomenon in lieu of the dual nature of time and the combination of objective and subjective time. The Elizabethan bard was not possibly aware of the findings of modern theories on subjective time, MTT, and other concepts associated with them. However, he versifies these theories in his sonnets and even goes beyond the findings of modern scholarship by using philosophical metaphors and analogies from nature that enrich the rhetorical force of the argument in these sonnets. Shakespeare's demonstration of the Aristotelian concept of chronological time places him within the traditions of the Renaissance which was informed and inspired by the massive movement of humanism. Yet Shakespeare is a poet of all times. Harold Bloom best describes his universality:

I hardly see how one can begin to consider Shakespeare without finding some way to account for his pervasive presence in the most unlikely contexts: here, there, and everywhere at once. He is a system of northern lights, an aurora borealis visible where most of us will never go (Bloom, 1998, p. 27).

\section{References}

Addis, D., Wong, A., \& Schacter, D. (2007). Remembering the past and imagining the future: Common and distinct neural substrates during event construction and elaboration. Neuropsychologia, 45(7), 1363-1377. https://doi.org/10.1016/j.neuropsychologia.2006.10.016

Arzy, S., Collette, S., Ionta, S., Fornari, E., \& Blanke, O. (2009). Subjective mental time: The functional architecture of projecting the self to past and future. European Journal of Neuroscience, 30, 2009-2017. https://doi.org/10.1111/j.1460-9568.2009.06974.x

Bar, M. (2007). The proactive brain: using analogies and associations to generate predictions. Trends of Cognitive Science, 11, 280-289. https://doi.org/10.1016/j.tics.2007.05.005

Barba, D. (2002). Memory, consciousness, and temporality. Norwell: Kluwer Academic Publishers. https://doi.org/10.1007/978-1-4615-1741-2

Bloom, H. (1998). Shakespeare's universalism. In Shakespeare (Ed.), The Invention of the human (pp. 25-41). New York: Riverhead Books.

Breuer, H. (2004). Oscar Wilde's Dorian Gray and Shakespeare's Sonnets. English Language Notes, 42(2), 59-68. https://doi.org/10.1215/00138282-42.2.59

Corballis, M. (2013). Mental time travel and the evolution of the human mind. Genet. Frontiers in Psychology, 4 , 1-8. https://doi.org/10.3389/fpsyg.2013.00485

Daniel, L. S., \& Donna, R. A. (2009). Remembering the past to imagine the future: A cognitive neuroscience perspective. Military Psychology, 21(Suppl. 1), S108-S112. https://doi.org/10.1080/08995600802554748

Duncan-Jones, K. (Ed.). (1997). Shakespeare: The sonnets. London: The Arden Shakespeare.

Hardie, R. P., \& Gaye, R. K. (trans.). (2000). Aristotle: Physics (Book IV. 11, p. 23). Retrieved from http://classics.mit.edu/Aristotle/physics.4.iv.html

Hassabis, D., \& Maguire, E. (2007). Deconstructing episodic memory with construction. Trends in Cognitive Sciences, 11, 49-57. https://doi.org/10.1016/j.tics.2007.05.001

Ingvar, D. H. (1979). "Hyperfrontal" distribution of the cerebral grey matter flow in resting wakefulness: On the functional anatomy of the conscious state. Acta Neurologica Scandinavica, 60, 12-25. https://doi.org/10.1111/j.1600-0404.1979.tb02947.x

Ingvar, D. (1985). "Memory of the future": An essay on the temporal organization of conscious awareness. Human Neurobiology, 4(3), 127-136.

Klein, S., Robertson, T., \& Delton, A. (2010). Facing the future: Memory as an evolved system for planning future acts. Memory and Cognition, 38, 13-22. https://doi.org/10.3758/MC.38.1.13

Klein, S., Robertson, T., Delton, A., \& Lax, M. (2012). Familiarity and personal experience as mediators of recall when planning for future contingencies. Journal of Experimental Psychology: Learning, Memory, and Cognition, 38, 240-245. https://doi.org/10.1037/a0025200

Manning, L., Cassel, D., \& Cassel, J. (2013). St. Augustine's reflections on memory and time and the current 
concept of subjective time in mental time travel, review. Behavioral Sciences, 3, 232-243. https://doi.org/10.3390/bs3020232

Moreira, L. (2017). The conception of time in Shakespeare's sonnets. A Cor das Letras, 8, 247-264. https://doi.org/10.13102/cl.v9i1.1554

Rassi, F. (2014). Time from Aristotle's perspective. World Scientific News, 6, 43-49.

Schacter, D., Addis, D., \& Buckner, R. (2007). Remembering the past to imagine the future: the prospective brain. Nature Reviews, 8, 657-661. https://doi.org/10.1038/nrn2213

Shen, Y., \& Liu, F. (2016). A thematic study of Shakespeare's sonnets. English Language and Literature Studies, 6(2). https://doi.org/10.5539/ells.v6n2p102

Suddendorf, T., \& Corballis, M. (1997). Mental time travel and the evolution of the human mind. Genetic, Social, and General Psychology Monographs, 123, 133-167.

Suddendorf, T., \& Corballis, M. (2007). The evolution of foresight: What is mental time travel, and is it unique to humans? Behavioral and Brain Sciences, 30, 299-313, https://doi.org/10.1017/S0140525X07001975

Szpunar, K. (2011). On subjective time. Cortex, 47(3), 409-411 https://doi.org/10.1016/j.cortex.2010.07.008

Szpunar, K., Addis, D., McLelland, V., \& Schacter, D. (2013). Memories of the future: New insights into the adaptive value of episodic memory. Frontiers in Behavioral Neuroscience, 7(1), 47. https://doi.org/10.3389/fnbeh.2013.00047

Szpunar, K., Addis, D., \& Schacter, D. (2012). Memory for emotional simulations: Remembering a rosy future. Psychological Science, 23, 24-29, 32. https://doi.org/10.1177/0956797611422237

Szpunar, K., Watson, M., \& McDermott, K. (2007). Neural substrates of envisioning the future. Proceedings of the National Academy of Sciences, 104, 642-647. https://doi.org/10.1073/pnas.0610082104

Tulving, E. (1985). Memory and consciousness. Canadian Psychology, 26, 1-12. https://doi.org/10.1037/h0080017

Tulving, E. (2002). Episodic memory: From mind to brain. Annual Review of Psychology, 53, 1-25. https://doi.org/10.1146/annurev.psych.53.100901.135114

Wheeler, M., Stuss, D., \& Rotman, E. (1997). Toward a theory of episodic memory: The frontal lobes and autonoetic consciousness. Psychological Bulletin, 121(3), 331-354. https://doi.org/10.1037/0033-2909.121.3.331

\section{Copyrights}

Copyright for this article is retained by the author, with first publication rights granted to the journal.

This is an open-access article distributed under the terms and conditions of the Creative Commons Attribution license (http://creativecommons.org/licenses/by/4.0/). 